\title{
SMALL OILFIELD INTEGRATED PRODUCTION MANAGEMENT MODEL
}

\section{INTEGRALNI MODEL UPRAVLJANJA PROIZVODNJOM NA MALIM NAFTNIM POLJIMA}

\author{
Danilović Dušan ${ }^{1}$, Karović-Maričić Vesna ${ }^{1}$, Leković Branko ${ }^{1}$
}

Received: March 03, 2016

Accepted: April 15, 2016

\begin{abstract}
In this paper is presented the concept of integrated oil production management model. The model's main objective is to provide more efficient tool for oil production process management in terms of the technological and economical aspects.

Integrated oil production management model implies multidisciplinary approach which connects oil reservoir development and production with application of risk analysis. Model's task is to simulate behavior of the whole production system, enabling overcoming the weaknesses of conventional deterministic analysis and significantly enhancing oil production, as well as an investment decision making. In the article is presented shortly the application of integrated oil production management model at the oilfield "K". The ultimate goal was techno-economic analysis of managing production process, i.e. determination of production economic limit based on production history data, decline analysis and operating costs.
\end{abstract}

Key words: oil, production, management, integrated model, decision making

\begin{abstract}
Apstrakt: U radu je predstavljen koncept modela integralnog upravljanja proizvodnjom nafte. Glavni cilj modela je da obezbedi efikasniji alat za upravljanje procesom proizvodnje nafte uzimajući u obzir tehnološke i ekonomske aspekte.

Integralni model upravljanja podrazumeva multidisciplinarni pristup koji povezuje razvoj ležišta i proizvodnju uz primenu analize rizika. Zadatak modela je da simulira ponašanje kompletnog proizvodnog sistema, uz prevazilaženje slabosti konvencionalne determinističke analize, značajno poveća proizvodnju nafte i donošenje odluka.

U radu je prikazana primena inegralnog modela na primeru naftnog polja "K". Cij je bila tehno-ekonomska analiza upravljanja proizvodnim procesom, odnosno određivanje ekonomskog limita proizvodnje baziranog na istorijatu proizvodnje, analizi pada proizvodnje i operativnim troškovima.
\end{abstract}

Ključne reči: nafta, proizvodnja, upravljanje, integralni model, donošenje odluke

\footnotetext{
${ }^{1}$ University of Belgrade - Faculty of Mining and Geology, Đušina 7, 11000 Belgrade, Serbia, e-mails: dusan.danilovic@rgf.bg.ac.rs; vesna.karovic@rgf.bg.ac.rs; branko.lekovic@rgf.bg.ac.rs
} 


\section{INTRODUCTION}

The main characteristic of the small oilfields is that the capital investments in the research and putting the field into production are relatively high and their production is very sensitive to changes of oil prices and production costs. The research demands performing of a very expensive work in the field of geology, geophysics, while putting discovered oilfield into production requires development of producing wells, development of gathering stations, preparation and transport of the crude oil. Specific investments are higher for the smaller oilfields.

Small oilfield production management cannot affect major production costs and the crude oil price, but current operating costs can. Therefore, operating costs are the essential element for profitability of certain small oil field.

Operating costs include costs regarding well maintenance, surface installations maintenance and production process costs (energy, additives etc.). The fact that cost size for well maintaining takes the main part in the total costs, leads to a conclusion that all efforts in production managing are being focused on cost reduction. Number of production days during a year, as well as a quantity of produced oil, depends on equipment characteristics and conditions in the well.

In order to provide as much as it is possible larger amounts of produced oil, with as much as it is possible lower operating costs, managing the production needs to be integrally analyzed. This means that from production planning through production managing to actions taken in order for solving certain production problems, whole process needs to be treated as an integrated oil production management.

\section{INTEGRATED OIL PRODUCTION MANAGEMENT MODEL}

Integrated oil production management model implies multidisciplinary approach which connects oil reservoir development and production with application of risk analysis. Model's task is to simulate behavior of the whole production system, enabling overcoming the weaknesses of conventional deterministic analysis and significantly enhancing oil production, as well as an investment decision making. Technical and commercial risks are analyzed by numerical simulation which generates possible consequences for the essential technical and commercial parameters, both for the final identification of economical variability and potential decisions. Also, connection of technical and economic model provides more comprehensive risk analysis and its better estimate.

Since the primary goal of an investments into a new and/or existing oilfield is profit making, the application of integrated model will enable enhanced production with production cost decrease and minimum risks (Danilovic, 2001; Chow et al. 2000; Hayatdavoudi, 1999).

Concept of integrated management model (Danilovic, 2001) is presented in Figure 1. It consists of five essential parts: production planning, production management, problem solving, techno-economic and risk analysis.

Production planning is based on the evaluation of future production and possible production problem analysis. None of well activities, i.e. oilfield activities can be performed without estimate of well's production possibilities. Future production 
estimate involves calculation of available reserves and prognosis of an exploitation dynamics in certain production period. Production decline analysis is applied as an efficient method for future production prognosis. For defining and solving the potential production problems that include all periodical production interruption (due to paraffin, water and gas coning, chemical treatments, etc.), the Fourier analysis is applied. Also, production planning is based on production optimization by application of "Nodal" analysis. For each exploitation methods (free flowing and artificial lift methods) "Nodal" analysis defines optimal well's operating parameters for proposed production values.

The second part of integrated model involves production management. Production management is based on production data acquisition and processing, "Nodal" analysis and problem diagnosis. Production parameters are monitored, archived and analyzed for each applied exploitation method. Comparison of optimal parameters defined by "Nodal" analysis with the real ones, enables calculation of deviation value. Deviation values out of certain range points out to the existence of operating problem. In that case, problem diagnosis models are applied. By monitoring production data, especially the quantity of produced fluid (crude oil, gas, and reservoir water), water-oil ratio (WOR) and gas-oil ratio (GOR), as the first indicators, possible problem can be preventively diagnosed. For existing problems, diagnosis is done by production history analysis.

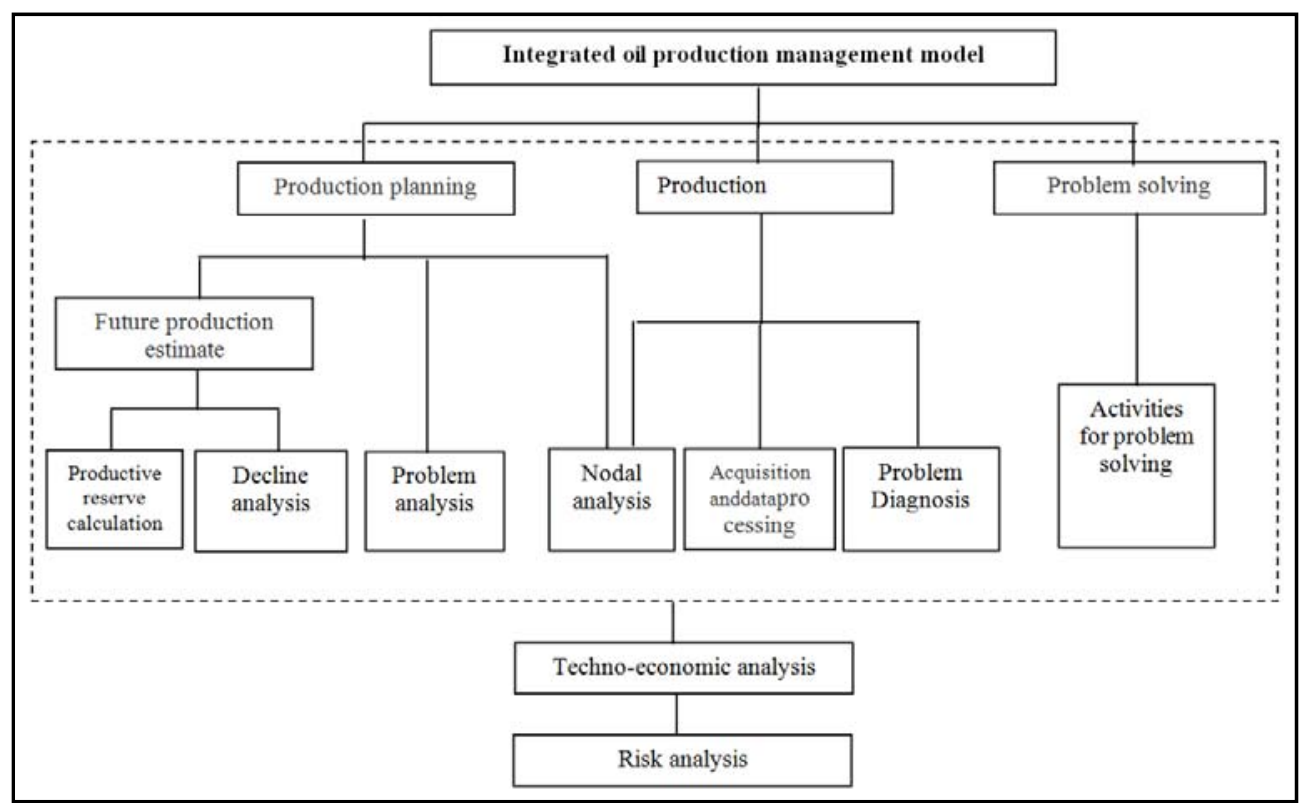

Figure 1 - Integrated oil production management model

After a production problem diagnosis, it is necessary to solve its cause. Third part of integrated management model is solving of problems that have affected the decrease in production comparing to the planned one. 
Fourth and fifth part of the Integrated Management Model involves technoeconomic and risk analysis. Risk analysis can be performed within each part of integrated management model or summarized after given technical solutions. Results are the same for both cases. Whether risk analysis will be performed for the purposes of risk evaluation of individual segments of the project or at the overall project level depends on concrete requests. If production of already producing field is analyzed, it is easier to perform risk analysis separately (for reserves calculation, future production prognosis, etc.). For new field or new well production designing, it is more adequate to perform risk analysis at the overall project level. It is important to emphasize that each suggested solution needs to be analyzed from the aspects of risk and cost-effectiveness. The same situation is with techno-economic analysis which can be done for certain parts of the project or for the whole project, which depends on the specific needs.

For each part of production process, the operating costs and costs of well's work over activities are defined. Plan of operating activities is made for each well, as well as for the whole oilfield on the basis of production history and problem diagnostics' analysis. For mature oilfields, redesigning of the production system capacity for produced fluid's preparation can be performed on the basis of planned fluid production dynamics in order to improve energy efficiency.

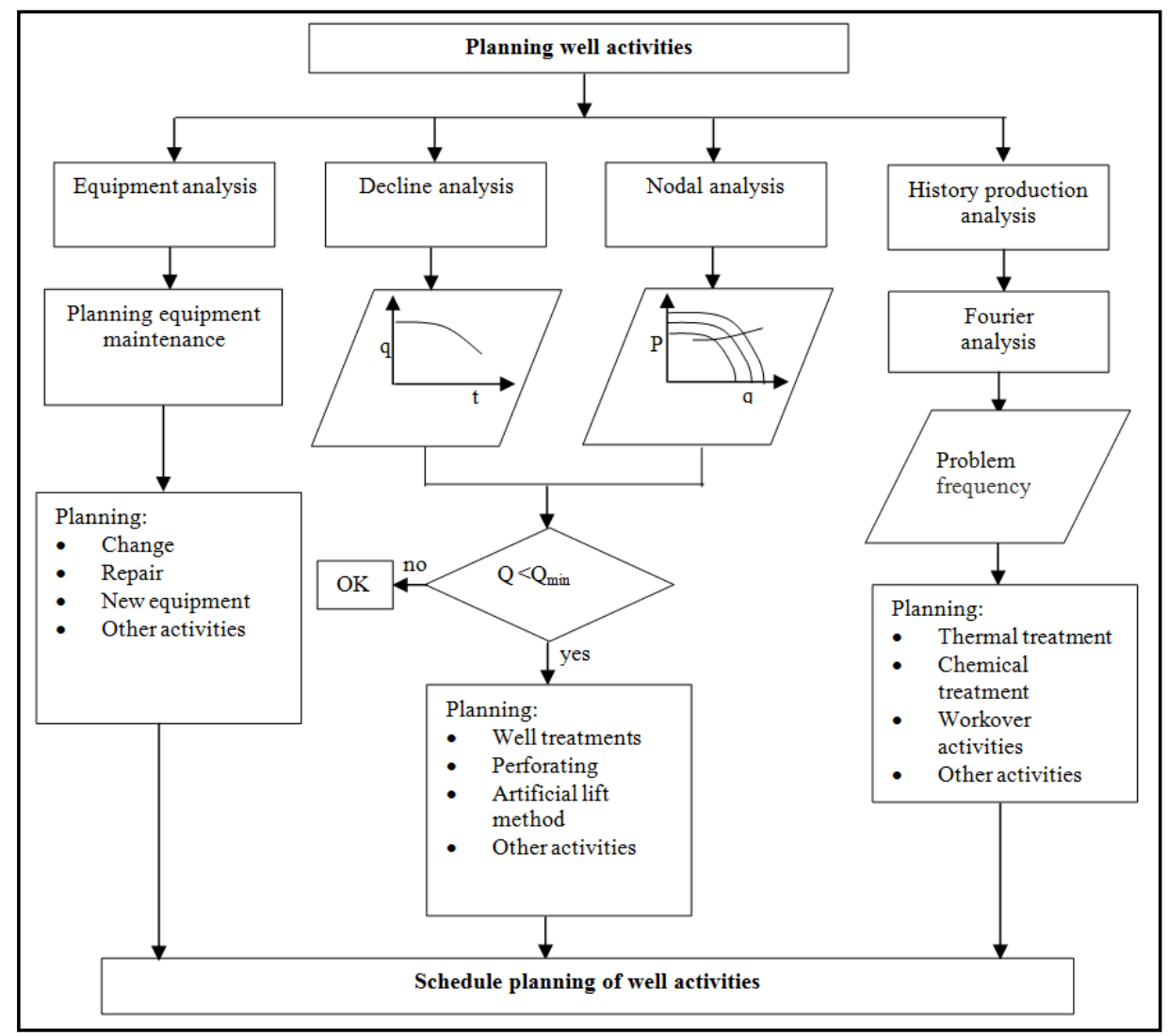

Figure 2 - Scheme of planning well activities 
Production process management directly depends on planning well activities. Parts of integrated oil production management model can be also successfully used for planning well activities. Since well activities require high investments, the goal is to perform each activity with as much as possible high success in optimal time. Also, it is very important to keep wells out of the production for the short time, for the reason that each production interruption reflects on the quantity of produced fluid. In Figure 2 is presented a scheme of planning well activities based on integrated oil production management model (Danilovic, 2001; Danilovic et al. 2010; Danilovic et al. 2011a, Danilovic et al. 2011b).

\section{DECISION MAKING PROCESS BASED ON INTEGRATED MODEL}

The primary task of integrated oil production management model is that application of all developed sub models (decline analysis, "Nodal" analysis, risk analysis etc.) provides realistic consideration of certain situation in order to make the best decisions in given circumstances. In Figure 3 is presented algorithm of decision making for well's operating activities by application of integrated management model. Based on the analysis of production trend, future fluid production dynamics can be obtained. By connecting methods for calculation of reserves with production trend analysis, very efficient tool is acquired which enables calculation of current and ultimate reservoir recovery and its future production behavior. This is very important for economic estimate of remaining fluid reserves.

Based on analysis of production history, the range of production changes is defined related to future production trend. Based on analysis of performed well activities, their number in future production period, operating costs and number of working days per year are being planned.

By application of economic model based on well activities costs and planned profit, cost-effectiveness of planned well activities is defined.

The most probable future production dynamics is defined by risk analysis and after that follows profit and cash flow calculation.

Performed economic and risk analysis present basis for decision making regarding planning the well's activities. 


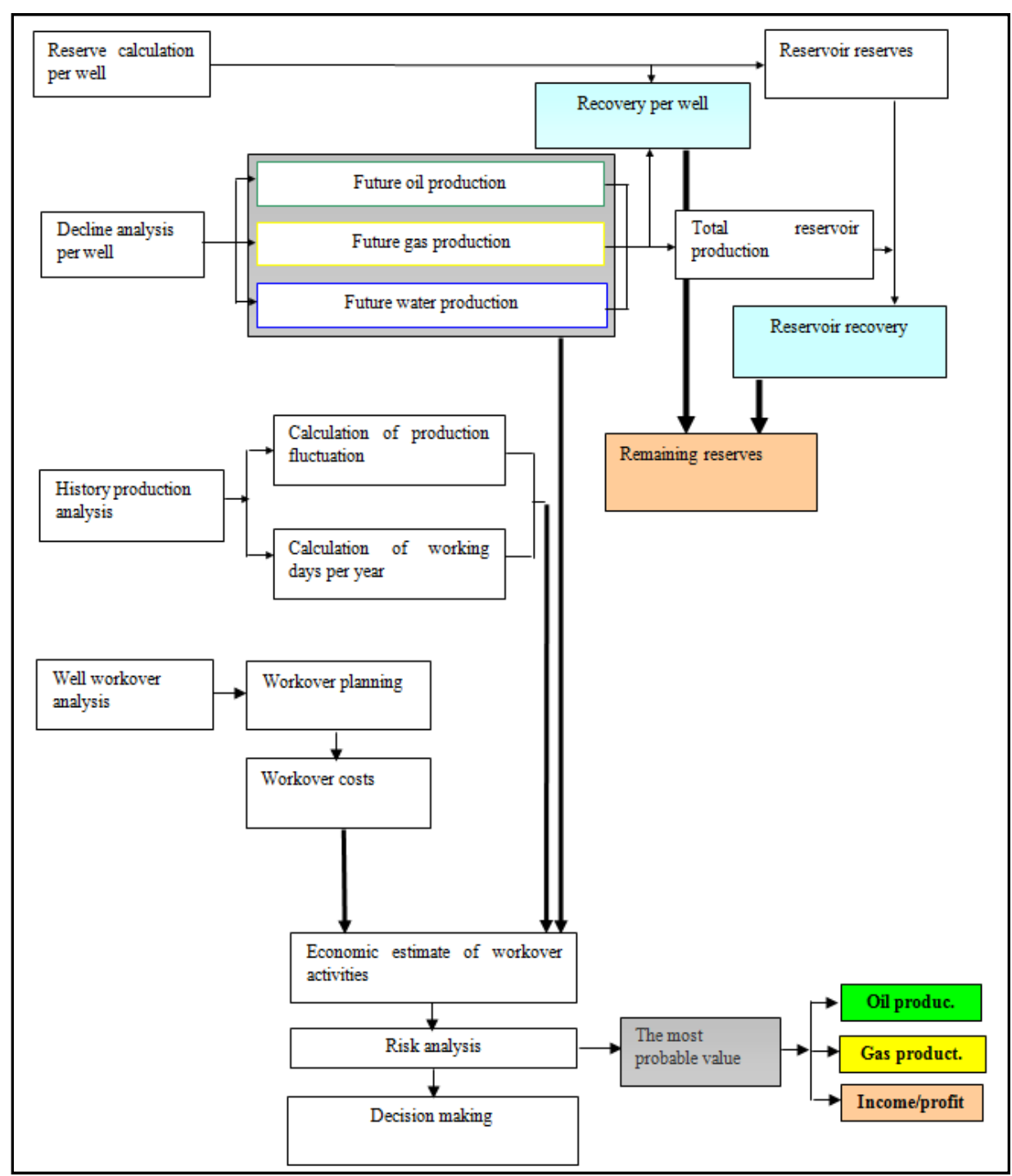

Figure 3 - Decision making for well's operating activities

\subsection{Brief application presentation}

In the article is presented shortly the application of integrated oil production management model at the oilfield "K". The ultimate goal was techno-economical analysis of managing production process, i.e. determination of production economic limit based on production history data, production decline analysis and operating costs.

This oilfield produces heavy oil from 35 wells and it has two gathering stations. The oil wells are producing approximately from $16 \mathrm{~m}^{3} /$ day to $25 \mathrm{~m}^{3} /$ day. 
Based on production parameters for each well, production decline analysis is done for the whole oilfield "K" (Figure 4). Analysis is done for 20 years, from 2015 to 2034.

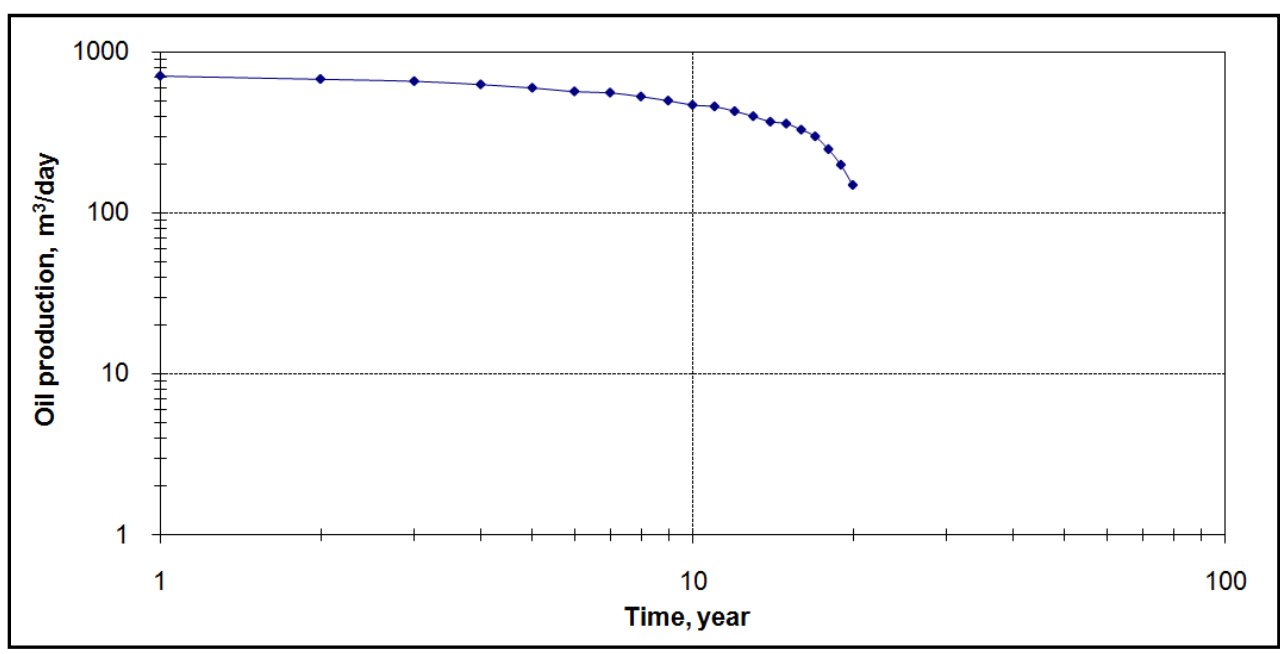

Figure 4 - Oil production decline analysis

Particular problem was determination of operating costs of the production process per unit of produced oil. Based on detailed analysis of total costs (Danilovic, 2011), calculated operating costs are $20.9 \$ / \mathrm{m}^{3}$.

Parameters for application of an economic model and cash flow calculation are defined and presented in the table 1.

Table 1 - Economic input parameters

\begin{tabular}{|l|r|}
\hline Oil production & $712 \mathrm{~m}^{3} /$ day \\
\hline Dayly operating costs & $20.9 \$ /$ day \\
\hline Oil price & $314 \$ / \mathrm{m}^{3}$ \\
\hline Average number of working days per month & $29.65 \mathrm{day} / \mathrm{month}$ \\
\hline
\end{tabular}

The most probable daily oil production iscalculated by risk analysis for 20152034 period (Figure 5) as well as related values of income, operating costs and profit. Risk analysis is performed on the basis of changes in daily oil production, number of working days per year and oil price with sofware RISK (Palisade, 1997).

For given parameters, the economic limit of production is $50 \mathrm{~m}^{3} /$ day and production period ends by 2035 .

Considering the costs of managing production process at the oilfield " $\mathrm{K}$ ",it should point out that special attention must be paid to the reduction of operating costs.

This will be especially important in the future period for the reason of production decrease and therefore, deterioration of cost-effectiveness, i.e. increase of specific production costs per unit of produced oil. 


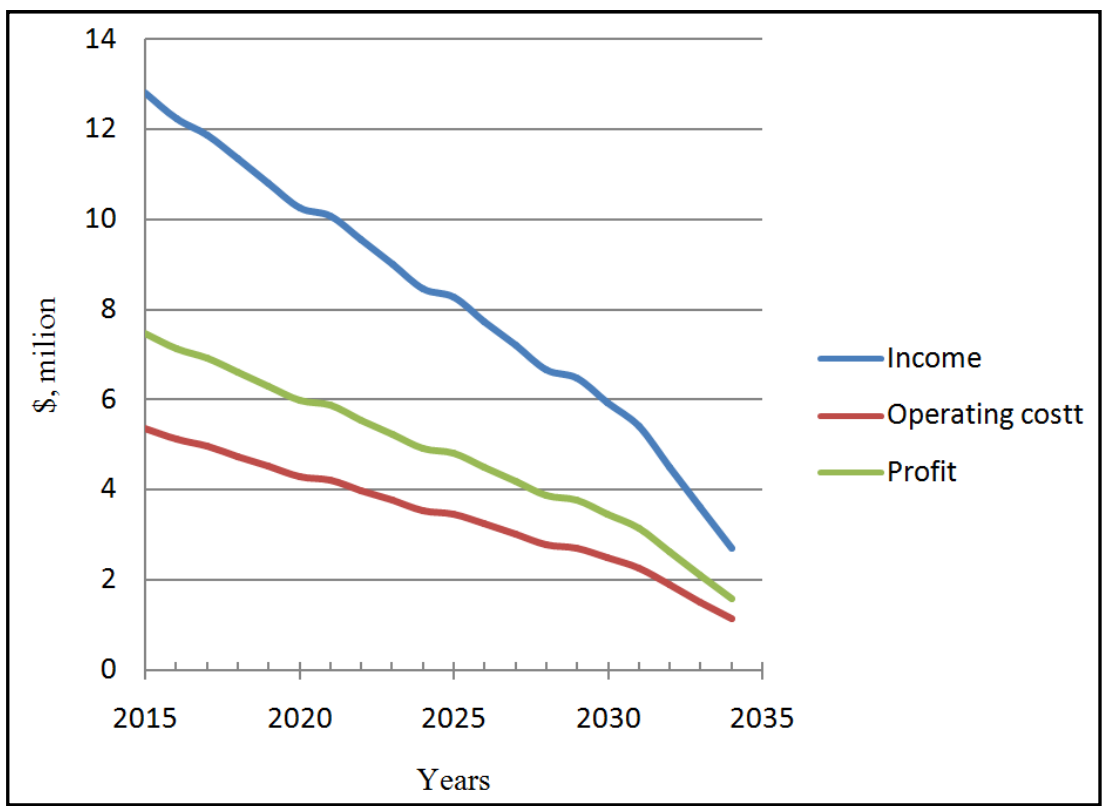

Figure 5 - The most probable values of income, operating costs and profit for 2015-2034 period

\section{CONCLUSION}

In this paper is presented the concept of the integrated oil production management model with main objective of achieving optimal production with lower operating costs and minimum risk. It means that the whole production process from production planning through production managing to actions taken in order for solving certain production problems, needs to be considered by integrated approach.

In the article is presented brief application of integrated oil production management model at the small oil field "K". By using the certain parts of the model such as production history data, decline analysis, operating costs and risk analysis, trends of future production, operating costs and profit are predicted for the field's exploitation period.

\section{REFERENCES}

[1] CHOW, C.V. et al. (2000) Managing Risk Using Integrated production Models: Applications. Journal of Petroleum Technology, 52(4), pp.94-98.

[2] DANILOVIC, D. (2001) Optimization of small oil field production applying the model of integrated management. (PhD), University of Belgrade - Faculty of Mining and Geology.

[3] DANILOVIC, D., KAROVIC-MARICIC, V. and COKORILO, V. (2010) Solving paraffin deposition problem in tubing by heating cable application. Thermal Science, 14, pp.247-253. 
[4] DANILOVIC, D. et al. (2011) Device for more efficiency production of heavy oil. Chemical Engineering Research and Design, 90(2), pp.238-242.

[5] DANILOVIC, D. et al. (2011) Laboratory testing and simulation of the paraffin deposition in Turija field oil well in Vojvodina. Hemijska industrija, 65(3), pp.249-256.

[6] HAYATDAVOUDI, A. (1999) Effect of Water-Soluble Gases on Production Decline, Production Stimulation and Production Management. In: SPE International Symposium on Oilfield Chemistry, Houston, February 1999. Houston: Society of Petroleum Engineers, pp.1-16.

[7] PALISADE CORPORATION (1997) @RISK - Risk Analysis and Simulation, [Software], version 4.0, Ithaca: Palisade Corporation. 